\title{
The role of social media marketing and brand image on smartphone purchase intention
}

\author{
Citra Savitri $^{\mathbf{a}^{*}}$, Ratih Hurriyatia ${ }^{\mathrm{a}}$ Lili Adi Wibowo ${ }^{\mathrm{a}}$ and Heny Hendrayatia
}

\begin{abstract}
${ }^{a}$ School of Postgraduate, Universitas Pendidikan Indonesia
\section{H R O N I C L E}

Article history:

Received: June 18, 2021

Received in revised format: June

29, 2021

Accepted: September 15, 2021

Available online: September 16, 2021

Keywords:

Social Media Marketing

Brand Image

Purchase Intention

Millennial Smartphone Consumers

\section{A B S T R A C T}

The purpose of this study was to analyze the relationship between Social Media Marketing and Brand Image, Social Media Marketing relationship and Purchase Intention, Brand Image Relationship and Purchase Intention and finally, the relationship between Social Media Marketing and Purchase Intention through Brand Image. The approach in the research used is a quantitative approach using PLS-SEM SmartPLS software as a data processing tool. In this study, the data collection technique was carried out using a questionnaire or online questionnaire which was distributed to 234 respondents of Millennial Smartphone Consumers in Banten Indonesia. Sampling system was accomplished with a snowball sampling method. Based on the results of hypothesis testing, it was found that there was a positive and significant relationship between Brand Image (BRI) and Purchase Intention. There was also a positive and significant relationship between Social Media Marketing and Brand Image. However, there was an insignificant relationship between Social Media Marketing and Brand Image while there was a significant relationship between Social Media Marketing and Purchase Intention through Brand Image as Mediator.
\end{abstract}

(C) 2022 by the authors; licensee Growing Science, Canada.

\section{Introduction}

The rapid development of communication tools provides opportunities for telecommunications companies (Ahmed \& Zahid (2014). Its current development can be seen with a communication tool in the form of a cell phone. Mobile is a communication tool that is currently being used by various groups, both young and elderly, since with cellphones everyone can communicate smoothly anywhere and anytime. According to Andika et al. (2021), the basic use of cellphones in the past could only be used to communicate via telephone and short messages, but with the development of the era, the features contained in cell phones have become increasingly diverse ranging from screens that were originally only black and white to colorful ones. They also have a camera feature to have a camera that is currently growing better from time to time. Since the advent of internet technology, the internet has become part of the cell phone. The increasingly complex wants and needs of consumers demand all the latest features operating in one communication tool. Mobile phone products that are currently developing are starting to develop into a gadget or can also be called a Smartphone. Electronic commerce or e-commerce is the buying, selling and marketing of goods and services through electronic systems, such as radio, television and computer networks or the internet. According to Ebrahim (2020), E-marketing in Indonesia is now showing a positive response (Nadaraja \& Yazdanifard, 2013). This is because the market generated in Indonesia is very wide and diverse and a marketing or sales system like this can reach all of Indonesia at the same time without having to set up branch offices in each area and can be done 24 hours without stopping. According to Sanny et al. (2020), the use of the internet in Indonesia is dominated by social media, this is what makes e-marketing increasingly growing where marketing practices through social media are used as a product marketing tool to promote the brand and brand of a company. Consumers will also find it easier to find information about the products they want to buy because they do not need to meet face-to-face directly. According to Yuliantoro et al. (2019), social media

* Corresponding author.

E-mail address: citra.savitri@ubpkarawang.ac.id (C. Savitri)

(C) 2022 by the authors; licensee Growing Science, Canada. doi: $10.5267 /$ j.ijdns.2021.9.009 
is content containing information, created by people who use publishing technology, very accessible and intended to facilitate communication, influence and interaction with others and with the general public. The high use of social media as a tool in marketing products makes the marketing reach wider. According to Haudi et al. (2021), the more a product is seen on social media, the higher the frequency of the product is being discussed and it can foster promotion through word of mouth where people who do not see the product directly on social media can find out about the product. In conditions of increasingly fierce competition, to be able to continue to survive in business, efforts are needed by the company in order to win the market. People's needs for the same product can be met by many similar products with different brands. According to Yuliantoro et al. (2019) in winning the competition, every company must have the right marketing strategy for the products it produces. Among the many marketing strategies, companies are faced with branding or branding. A brand is essentially a marketer's promise to deliver certain and continuous characteristics, benefits, and services to consumers. Brand image is a set of consumer beliefs about a particular brand. Brand Image is important and a top priority for business owners since consumers will make a reference before making a purchase.

According to Kazmi and Mehmood (2020), a good or positive brand image is the one that can have an added value impact on consumers, if a brand has a bad image, it will indirectly affect consumers and most likely consumers are not interested in making a purchase. According to Pramono et al. (2021), the company is required to carry out a good and correct strategy in order to attract attention to consumers and not lose competitiveness with other businesspeople. For companies, brand image is the perception given by consumers to the products or services provided by the company to consumers. Brand image is the perception that consumers have of the valuation for the company that persists in consumers' minds. According to Affandi et al. (2020) and Prahiawan et al. (2021) consumers in this case are those who have made a purchase and they are aware of the meaning of the brand image. A good brand image will be easily accepted by consumers, thereby increasing customer satisfaction. Purchase decisions made by consumers are decisions made after consumers analyze various alternatives or information from products or services. According to Faircloth et al. (2001) and Purba et al. (2021), consumer purchasing decisions are made through various processes. For marketers, it is very important to analyze the buying decision process made by consumers. Marketers will try to influence the consumers' mind to choose the products or services they offer in various ways. When viewed from the company's point of view, the company will get excessive profits since each product has a place in the hearts of consumers and will clearly increase the target market. According to Faircloth et al. (2001), an effective brand image can reflect three things, namely: building product character and providing proportional value, conveying product character uniquely so that it is different from its competitors, giving emotional strength from rational power. According to Dash et al. (2021) a company that can form a good brand image will be able to carry out promotions easily and effectively to consumers who have a great opportunity to increase customer loyalty, but if it has a bad brand image it will be valuable otherwise.

The purpose of this study was to analyze the relationship between Social Media Marketing (SCM) to Brand Image (BRI), Social Media Marketing (SCM) Relationship to Purchase Intention (PIN), Brand Image Relationship (BRI) to Purchase Intention (PIN) and the relationship between Social Media Marketing (SCM) on Purchase Intention (PIN) through Brand Image (BRI).

\section{Method}

The research method used is a quantitative approach. This quantitative approach is executed by collecting data in the form of numbers. The data in the form of numbers are then processed and analyzed to obtain scientific information behind these numbers (Purwanto et al., 2021). In this study, the data obtained went through a testing process with SEM-PLS Software. This study used PLS-SEM since the model tested was the development of the previous research model. Analyzing the data with PLS-SEM can be accomplished in two ways, namely the Measurement Model which is often called the Outer model and the Structural model called the Inner Model. The research design used in this study is the causal associative method. The casual associative method is the research that looks for the causal effect of the variables to be studied. Data collection techniques are methods or methods used to obtain the data needed for a study. In this study, the data collection technique was carried out using a questionnaire or online questionnaire which was distributed to 234 consumer respondents. Sampling system with snowball sampling method.

\subsection{Validity test}

With the aim of knowing the validity or invalidity of the statement used in the questionnaire, the statement is declared valid if the statement used indicates something that will be measured Latan et al. (2017). Validity testing focuses on all variables that have a unidimensional form. For this study, using convergent validity testing, namely through the Average variance extracted (AVE) value for each Latan et al. (2017). Validity of an indicator if the AVE value is equal to or more than 0.5

\subsection{Reliability Test}

To see the accuracy, and consistency of the model can be measured using the reliability test, in the SmartPLS 3.0 program there are two ways to test the instrument model, namely Cronbach's Alpha and Composite Reliability, but usually the results of Cronbach's Alpha test have a lower value, therefore Latan et al. (2017) prefers that reliability testing be carried out using 
Composite Reliability. Latan et al. (2017) believe that the assumption of accurate parameter estimates is tested using Composite Reliability, in Composite Reliability testing there is the use of the Rule of thumb to measure the reliability of a variable. Composite Reliability is said to be valid if the value is more than 0.7 (Purwanto et al., 2021).

\subsection{Structural Model Test}

This test is used to calculate the significance value of the relationship between variables directly without mediation. In the SmartPLS 3.0 program, the magnitude of the value of the relationship between variables can be seen through the Sample Mean table in the Path coefficients. To see the relationship between variables is significant or not, we can see in the T-Statistics table where the value must be more than $>1.96$, or the P-Value (Betta) is less than $<0.05$ (Latan et al., 2017).

\section{$R$ Square (Coefficient of Determination Test)}

The correlation test uses the coefficient of determination $\left(\mathrm{R}^{2}\right)$ between the independent variables and the dependent variable with the aim of seeing whether there is a relationship between the Independent Variable and the Dependent Variable. The results of the coefficient of determination test $\left(\mathrm{R}^{2}\right)$ also show how much the independent variable explains the independent variable. An independent variable is said to contain the information needed by the dependent variable if it has an R-Square value of 1 (one) or at least close to it, and vice versa (Purwanto et al., 2021).

\section{Quality Index}

The test is to assess the model in an overall way. The test is to assess the model in an overall way. The Quality Index is measured by looking at the value of GoF (Goodness of fit), the better the resulting model can be seen from the higher the GoF value, GoF Small =0.10, GoF Medium = 0.25, GoF Large 0.36 (Purwanto et al., 2021).

\section{Hypothesis testing}

According to Hair et al. (2019) after a research model is believed to be fit, a hypothesis test can be carried out. The next step is to test the hypothesis that has been built in this study. In this case, the bootstrapping method is applied to the sample. Testing with bootstrapping is intended to minimize the problem of abnormal research data. The last step of the test using the Smart Pls application is hypothesis testing and is carried out by looking at the results of the bootstrapping value. The hypothesis is accepted when the significance level is less than 0.05 or the t-value exceeds the critical value (Hair et al., 2014). The value of $\mathrm{t}$ statistics for the $5 \%$ significance level is 1.96 .

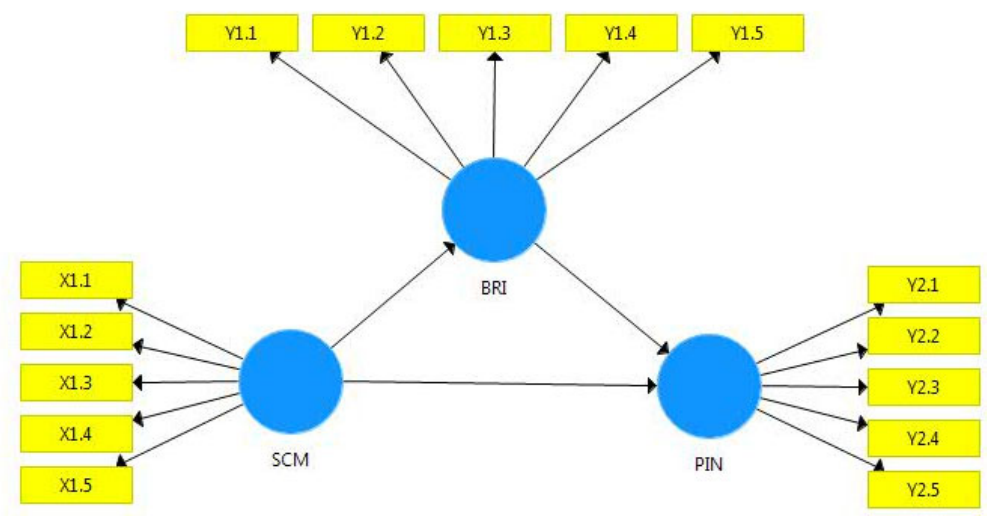

Fig. 1. Research Model

Hypothesis 1: There is a positive relationship between Social Media Marketing (SCM) and Brand Image (BRI).

Hypothesis 2: There is a positive relationship between Social Media Marketing (SCM) and Purchase Intention (PIN).

Hypothesis 3: There is a positive relationship between Brand Image (BRI) and Purchase Intention (PIN).

Hypothesis 4: There is a positive relationship between Social Media Marketing (SCM) and Purchase Intention (PIN) through Brand Image (BRI).

\section{Result and Discussion}

\subsection{Reliability test}

According to Hair et al. (2019) and Purwanto et al. (2021), the reliability is a measure of the internal consistency of indicators of a construct which shows the degree to which each of these indicators shows a general latent construct. According to Hair 
et al. (2019), the reliability requirement is a measure of the stability and consistency of the results at different times. To test the reliability of the construct in this study we have used the value of composite reliability. A variable is said to meet construct reliability if it has a composite reliability value $>0.7$ (Purwanto et al., 2019) and the alpha Cronbach value $>0.7$ has a good level of reliability for a variable.

Table 1

Reliability Testing Result

\begin{tabular}{lllll}
\hline & Cronbach's Alpha & rho_A & Composite Reliability & Average Variance Extracted (AVE) \\
\hline BRI & 0.928 & 0.93 & 0.945 & 0.775 \\
PIN & 0.866 & 0.892 & 0.905 & 0.66 \\
SCM & 0.901 & 0.91 & 0.927 & 0.719 \\
\hline
\end{tabular}

In Table 1, it can be seen the results of the reliability test analysis using the SmartPLS tool which states that all composite reliability values are greater than 0.7 , which means that all variables are reliable and have met the test criteria. Furthermore, the value of Cronbach's omission also shows that all Cronbach's alpha values are more than 0.6 and this indicates the level of reliability of the variable has also met the criteria. After the results of the test data are declared reliable, the next step is to test the validity including loading factor, AVE, Farnell Larcker Criterion and cross loading. The steps that need to be taken are selecting the outer loading menu to see the results of the loading factor test, then the discriminant validity menu to see the results of the Fornell Larcker criterion and cross loading tests.

\subsection{Convergent Validity}

Convergent validity is used to measure the correlation between item scores and construct scores, the higher the correlation the better the data validity (Purwanto et al., 2021). Measurement can be categorized as having convergent validity if the loading factor value is $>0.7$.

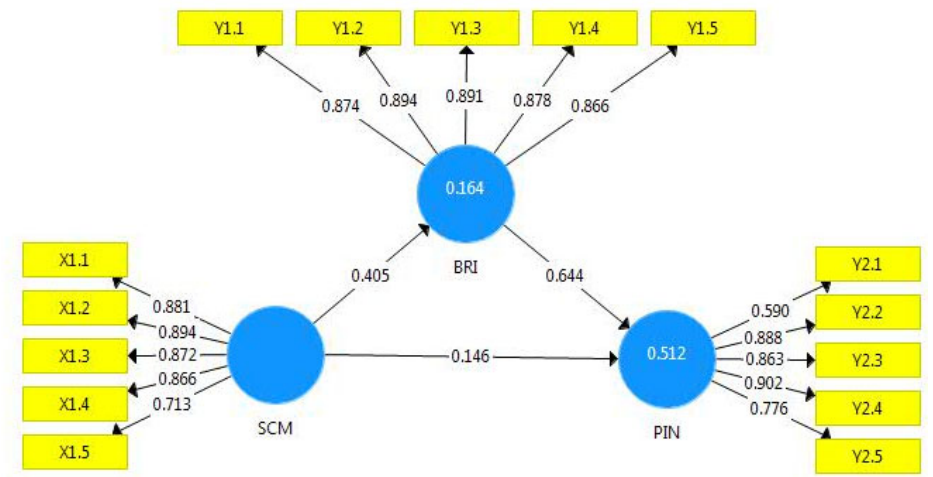

Fig. 2. Validity Testing

\subsection{Discriminant Validity}

Discriminant validity is a test of construct validity by predicting the size of the indicator from each block (Hair, 2019). One of the discriminant validities can be seen by comparing the AVE value with the correlation between other constructs in the model. If the AVE root value is $>0.50$, it means that discriminant validity is reached (Hair, 2018). Discriminant validity was also carried out based on the Fornell Larcker Criterion measurement with the construct. If the correlation of the constructs on each indicator is greater than the other constructs, it means that latent constructs can predict indicators better than other constructs (Purwanto et al., 2020).

Table 2

Discriminant validity Result

\begin{tabular}{llll}
\hline & BRI & PIN & SCM \\
\hline BRI & 0.88 & & \\
PIN & 0.703 & 0.812 & 0.848 \\
SCM & 0.405 & 0.407 & 0 \\
\hline
\end{tabular}

Based on Table 2, it appears that each statement indicator has the highest loading factor value in the tested latent constructs than other latent constructs, meaning that each statement indicator can be predicted well by each latent construct in other words discriminant validity is valid. 


\section{$R$ Square Value}

The value of $\mathrm{R}$ square $\left(\mathrm{R}^{2}\right)$ is a measure of the proportion of the variation in the value of the affected variable which can be explained by the variable that influences it. If in a study using more than two independent variables, then the adjusted RSquare (adjusted $R^{2}$ ) is used. The value of $r$ square adjusted is a value that is always smaller than $r$ square. The $R^{2}$ value is close to 1 , with the limiting criteria being divided into 3 classifications, namely:

If the value of $\mathrm{R}^{2}=0.67$ Model is substance (strong),

If the value of $\mathrm{R}^{2}=0.33$ the model is moderate (medium),

If the value of $\mathrm{R}^{2}=0.19$ the model is weak (bad).

Table 3

$\underline{\text { R-Square Value }}$

\begin{tabular}{lll}
\hline & R Square & R Square Adjusted \\
\hline BRI & 0.164 & 0.155 \\
PIN & 0.512 & 0.501 \\
\hline
\end{tabular}

Based on Table 3, the R-Square for Brand Image (BRI) value of 0.155 or $15.5 \%$ means that the Brand Image variable is influenced by the Social media marketing variable by $15.5 \%$, while the remaining $85.5 \%$ is influenced by other variables not discussed in this study. Purchase Intention (PIN) variable is influenced by Social media marketing and brand image variables by $50.1 \%$, while the remaining $49.9 \%$ is influenced by other variables not discussed in this study.

\section{Hypothesis testing}

According to Hair et al. (2019) after a research model is believed to be fit, a hypothesis test can be carried out. The next step is to test the hypothesis that has been built in this study. In this case, the bootstrapping method is applied to the sample. Testing with bootstrapping is intended to minimize the problem of abnormal research data. The last step of the test using the Smart Pls application is hypothesis testing and is carried out by looking at the results of the Bootstrapping value. Hypothesis testing using the Bootstrapping function on SmartPLS 3.0. The hypothesis is accepted when the significance level is less than 0.05 or the t-value exceeds the critical value (Hair et al., 2014). The value of t statistics for the 5\% significance level is 1.96 .

Table 4

Hypothesis Testing

\begin{tabular}{ccccc}
\hline Correlation & Original Sample $(\mathrm{O})$ & T Statistics & P Values & Note \\
\hline $\mathrm{BRI} \rightarrow$ PIN & 0.644 & 7.955 & 0.000 & Significant \\
$\mathrm{SCM} \rightarrow$ BRI & 0.405 & 3.914 & 0.000 & Significant \\
$\mathrm{SCM} \rightarrow$ PIN & 0.146 & 1.44 & 0.151 & Not Significant \\
$\mathrm{SCM} \rightarrow$ BRI $\rightarrow$ PIN & 0.261 & 3.476 & 0.001 & Significant \\
\hline
\end{tabular}

\section{Relationship between Brand Image (BRI) and Purchase Intention (PIN)}

Based on the results of the hypothesis testing, the original sample value was positive 0.146 and the T value was $7.955>1.96$ and $\mathrm{P}$ value $0.000<0.050$ so it was concluded that there was a positive and significant relationship between Brand Image (BRI) and Purchase Intention (PIN). Brand image has a big role in influencing consumer purchasing decisions. The popularity of the brand and the company's ability to serve and meet consumer needs will determine the public's impression of the brand image. According to Stephen (2016), Wijayaa et al. (2022) and Wanasida (2021) brands that have a good image of their products tend to be preferred and easier to accept than the brands that have a bad image or a neutral image. Image Brands are often used as a reference by consumers to make purchasing decisions when the consumer has no experience or knowledge of a product. With the brand, customers can easily distinguish the products they will buy with other products in terms of quality, satisfaction, pride, or attributes others attached to the brand. According to Rudyanto et al. (2020) brand trust forms a brand or brand image related to the existence of a brand image, brand awareness of a product category also becomes very important in marketing a product, so that it can be said that promotion and brand awareness are elements that can be combined useful in order to produce an achievable response in the target market. Therefore, with the right strategy, a product will be able to attract the attention of potential candidates consumers and are able to provide a sense of buying interest in the product.

\section{Relationship between Social Media Marketing (SCM) and Brand Image (BRI)}

Based on the results of the hypothesis testing, the original sample value was positive 0.405 and the $\mathrm{T}$ value was $3.914>1.96$ and $\mathrm{P}$ value $0.000<0.050$ so it was concluded that there was a positive and significant relationship between Social Media Marketing (SCM) and Brand Image (BRI). According to Nagoya et al. (2021) and Rudyanto et al. (2020), Social media has a characteristic where the message conveyed by a user is conveyed not only to one user but also is conveyed to many users at once, so that the message conveyed tends to be faster than other media. The use of social media who sees the product has a higher probability of indirectly talking about the product and promoting it to other consumers who do not use social media. Therefore, the higher the use of social media, the higher the opportunity for a product to be discussed by the public. The 
results of this study are in line with the results of research conducted by Rudyanto et al. (2020) and Stephen (2016) stating that social media marketing has a significant effect on Brand Image (BRI). And supported by the results of research conducted by Ashari Nurrokhmana and Setyawan (2018) also stated that social media marketing has a positive and significant impact on Brand Image (BRI).

\section{Relationship between Social Media Marketing (SCM) and Purchase Intention (PIN)}

Based on the results of the hypothesis testing, the original sample value was positive 0.146 and the $\mathrm{T}$ value was $1.44<1.96$ and the $\mathrm{P}$ value was $0.151>0.050$ so it was concluded that there was an insignificant relationship between Social Media Marketing (SCM) and Brand Image (BRI). Social media marketing is a form of marketing that uses social media to market a product, service, brand or issue by utilizing the audiences who participate in the social media. By using social media marketing, it is hoped that the products marketed can be known more widely by consumers who are far from the company's location so that they can improve consumer purchasing decisions. The results of this study are also reinforced by the results of other studies by Faircloth et al. (2001), Yuliantoro et al. (2019), Park and Oh (2012), Pramono et al. (2021) which state that social media marketing has a positive and significant impact on purchasing decisions.

\section{The relationship between Social Media Marketing (SCM) and Purchase Intention (PIN) through Brand Image (BRI)}

Based on the results of the hypothesis testing, the original sample value is positive 0.261 and the $\mathrm{T}$ value is $3.476>1.96$ and $\mathrm{P}$ value is $0.001<0.050$, so it can be concluded that there is a significant relationship between Social Media Marketing (SCM) and Purchase Intention (PIN) through Brand Image (BRI) so that the brand image variable is a full mediator variable. The results of testing the direct relationship of social media marketing variables to purchasing decisions show a significant relationship and the indirect relationship of social media marketing to purchasing decisions through Brand Image (BRI) also shows a significant relationship. So, it can be concluded that Brand Image (BRI) is able to mediate the relationship between social media marketing and purchasing decisions. According to Faircloth et al. (2001), Yuliantoro et al. (2019), Park and Oh (2012), Pramono et al. (2021), Nagoya et al. (2021) and Ronald et al. (2020), social media can be used to encourage a consumer to express his/her opinion on the product or service offered, and publish his/her opinion in social networks on the internet, which can later increase the knowledge of consumers who read the comments or opinions of that person on the market and the goods or services offered so that they are more likely to inform friends and colleagues about the products they see. Therefore, Brand Image (BRI) can indirectly improve consumer purchasing decisions. The results of research conducted by Park and Oh (2012), Pramono et al. (2021), Nagoya et al. (2021), Ronald et al. (2020) state that social media marketing has a positive and significant effect on purchasing decisions. Oktavianto (2013) states that the WOM variable has a positive influence and has a strong influence on purchasing decisions. Research by Wijaya et al. (2021), Nagoya et al. (2021), Ronald et al. (2020) state that Brand Image (BRI) is able to mediate the relationship between social media marketing on purchasing decisions

\section{Conclusion}

Based on the results of hypothesis testing, it was found that there is a positive and significant relationship between Brand Image (BRI) and Purchase Intention (PIN). There is a positive and significant relationship between Social Media Marketing (SCM) and Brand Image (BRI). There is an insignificant relationship between Social Media Marketing (SCM) and Brand Image (BRI). There is a significant relationship between Social Media Marketing (SCM) and Purchase Intention (PIN) through Brand Image (BRI). Social media marketing has a positive effect on purchasing decisions, which means that if the use of social media marketing increases, purchasing decisions will also increase.) Social media marketing has a positive effect on brand image, which means that if the use of social media increases then brand image will also increase. on purchasing decisions, which means that if brand image increases, purchasing decisions will also increase. Brand image is able to mediate the relationship between social media marketing and purchasing decisions, which means that if brand image increases, the relationship between social media marketing and purchasing decisions will also increase. with only 234 people, the use of social media is also very high, of course it is still not enough to describe the actual situation in the field. The variables used are also the best. bag to social media marketing and brand image to purchasing decisions where there are many other variables that can influence purchasing decisions. It is recommended for producers to further increase online communities by inviting more consumers.

\section{References}

Affandi, A., Sarwani, A. S., Erlangga, H., Siagian, A. O., Purwanto, A., Effendy, A. A., ... \& Juhaeri, G. (2020). Optimization of MSMEs Empowerment in Facing Competition in the Global Market during the COVID-19 Pandemic Time. Systematic Reviews in Pharmacy, 11(11), 1506-1515.

Ahmed, M. A., \& Zahid, Z. (2014). Role of social media marketing to enhance CRM and brand equity in terms of purchase intention. Asian Journal of Management Research, 4(3), 533-549.

Andika, R., Kao, C. T., Williams, C., Lee, Y. J., Al-Battah, H., \& Alweis, R. (2021). YouTube as a source of information on the COVID-19 pandemic. Journal of Community Hospital Internal Medicine Perspectives, 11(1), 39-41. 
Ashari Nurrokhmana, B., \& Setyawan, A. A. (2018). Analisis Pengaruh Social Media Marketing, Brand Image, dan Brand Love Terhadap Word of Mouth Fashion Sportswear (Doctoral dissertation, Universitas Muhammadiyah Surakarta).

Dash, G., Kiefer, K., \& Paul, J. (2021). Marketing-to-Millennials: Marketing 4.0, customer satisfaction and purchase intention. Journal of Business Research, 122, 608-620.

Ebrahim, R. S. (2020). The role of trust in understanding the impact of social media marketing on brand equity and brand loyalty. Journal of Relationship Marketing, 19(4), 287-308.

Faircloth, J. B., Capella, L. M., \& Alford, B. L. (2001). The effect of brand attitude and brand image on brand equity. Journal of Marketing Theory and Practice, 9(3), 61-75.

Hair Jr, J. F., Hult, G. T. M., Ringle, C. M., \& Sarstedt, M. (2021). A primer on partial least squares structural equation modeling (PLS-SEM). Sage publications.

Hair, J. F., Risher, J. J., Sarstedt, M., \& Ringle, C. M. (2019). When to use and how to report the results of PLS-SEM. European business review.

Nadaraja, R., \& Yazdanifard, R. (2013). Social media marketing: advantages and disadvantages. Center of Southern New Hempshire University, 1-10.

Haudi, Rahadjeng, E.R., Santamoko, R., Putra, R.S., Purwoko, D., Nurjannah, D., Koho, I.R., Wijoyo, H., Siagian, A.O., Cahyono, Y., \& Purwanto, A. (2022). The role of e-marketing and e-CRM on e-loyalty of Indonesian companies during Covid pandemic and digital era. Uncertain Supply Chain Management, 10(1), 1-8.

Kazmi, A., \& Mehmood, Q. (2016). The effect of electronic word of mouth communication and brand image on purchase intention: A case of consumer electronics in Haripur, Pakistan. Management Science Letters, 6(7), 499-508.

Latan, H., Noonan, R., \& Matthews, L. (2017). Partial least squares path modeling. Partial least squares path modeling: basic concepts, methodological issues and applications. https://doi. org/10.1007/978-3-319-64069-3 DOI: https:/doi. org/10.1007/978-3-319-64069, 3.

Nagoya, R., Bernarto, I., Antonio, F., Pramono, R., Wanasida, A. S., \& Purwanto, A. (2021). EXPLORING INTENTION TO ENROLL UNIVERSITY USING AN EXTENDED STIMULUS-ORGANISM-RESPONSE MODEL. Academy of Strategic Management Journal, 20, 1-12.

Park, J., \& Oh, I. K. (2012). A case study of social media marketing by travel agency: The salience of social media marketing in the tourism industry. International Journal of Tourism Sciences, 12(1), 93-106.

Pramono, R., Sondakh, L. W., Bernarto, I., Juliana, J., \& Purwanto, A. (2021). Determinants of the small and medium enterprises progress: A case study of SME entrepreneurs in Manado. Indonesia. The Journal of Asian Finance, Economics, and Business, 8(1), 881-889.

Prahiawan, W., Fahlevi, M., Juliana, J., Purba, J., \& Tarigan, S. (2021). The role of e-satisfaction, e-word of mouth and etrust on repurchase intention of online shop. International Journal of Data and Network Science, 5(4), 593-600.

Purba, J., Samuel, S., \& Budiono, S. (2021). Collaboration of digital payment usage decision in COVID-19 pandemic situation: Evidence from Indonesia. International Journal of Data and Network Science, 5(4), 557-568.

Purwanto, A., Asbari, M., \& Santoso, T. (2021). Education Management Research Data Analysis: Comparison of Results between Lisrel, Tetrad, GSCA, Amos, SmartPLS, WarpPLS, and SPSS For Small Samples. Nidhomul Haq: Jurnal Manajemen Pendidikan Islam, 6(2), 382-399. https://doi.org/10.31538/ndh.v6i2.1575

Wijayaa, O., Sulistiyanib, S., Pudjowatic, J., Kurniasih, N., \& Purwanto, A. (2021). The role of social media marketing, entertainment, customization, trendiness, interaction and word-of-mouth on purchase intention: An empirical study from Indonesian smartphone consumers. International Journal of Data and Network Science, 5(3), 231-238.

Purwanto, A., Asbari, M., Santoso, T. I., Paramarta, V., \& Sunarsi, D. (2020). Social and Management Research Quantitative Analysis for Medium Sample: Comparing of Lisrel, Tetrad, GSCA, Amos, SmartPLS, WarpPLS, and SPSS. Jurnal Ilmiah Ilmu Administrasi Publik, 10(2), 518-532.

Purwanto, A., Asbari, M., Santoso, T. I., \& Haque, M. G. (2019). Marketing Research Quantitative Analysis for Large Sample: Comparing of Lisrel, Tetrad, GSCA, Amos, SmartPLS, WarpPLS, and SPSS. Jurnal Ilmiah Ilmu Administrasi Publik, $9(2), 355-372$.

Oktavianto, Y. (2013). Pengaruh Word of Mouth Terhadap Keputusan Pembelian Konsumen Pada Usaha Mie Ayam Pak Agus di Kota Batu. Manajemen Bisnis, 3(1).

Rudyanto, R., Soemarni, L., Pramono, R., \& Purwanto, A. (2020). The influence of antecedents of supply chain integration on company performance. Uncertain Supply Chain Management, 8(4), 865-874

Sanny, L., Arina, A., Maulidya, R., \& Pertiwi, R. (2020). Purchase intention on Indonesia male's skin care by social media marketing effect towards brand image and brand trust. Management Science Letters, 10(10), 2139-2146.

Susilo, R., Bernarto, I., \& Purwanto, A. (2020). Effect of trust, value and atmosphere towards patient satisfaction (case study on preama clay of wae laku, indonesia). International Journal of Advanced Science and Technology, 29(3), 6716-6723.

Stephen, A. T. (2016). The role of digital and social media marketing in consumer behavior. Current opinión in Psychology, 10, 17-21.

WANASIDA, A. S., BERNARTO, I., SUDIBJO, N., \& PURWANTO, A. (2021). The Role of Business Capabilities in Supporting Organization Agility and Performance During the COVID-19 Pandemic: An Empirical Study in Indonesia. The Journal of Asian Finance, Economics and Business, 8(5), 897-911. https://doi.org/10.13106/JAFEB.2021.VOL8.NO5.0897 
Yuliantoro, N., Goeltom, V., Juliana, I. B., Pramono, R., \& Purwanto, A. (2019). Repurchase intention and word of mouth factors in the millennial generation against various brands of Boba drinks during the Covid 19 pandemic. African Journal of Hospitality, Tourism and Leisure, 8(2), 1-11.

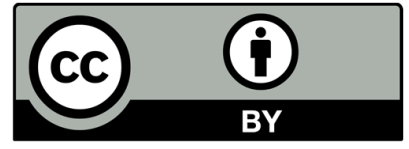

(C) 2022 by the authors; licensee Growing Science, Canada. This is an open access article distributed under the terms and conditions of the Creative Commons Attribution (CC-BY) license (http://creativecommons.org/licenses/by/4.0/). 